\title{
Biomaterials for bone regeneration: an orthopedic and dentistry overview
}

\author{
J. Girón ${ }^{1,20 \bowtie}$, E. Kerstner ${ }^{3 \oplus}$, T. Medeiros ${ }^{1,2}$, L. Oliveira ${ }^{1 \oplus}$, G.M. Machado ${ }^{4 \oplus}$, C.F. Malfatti ${ }^{3 \oplus}$, and \\ P. Pranke ${ }^{1,2,5}$ \\ ${ }^{1}$ Laboratório de Hematologia e Células Tronco, Faculdade de Farmácia, Universidade Federal do Rio Grande do Sul, \\ Porto Alegre, RS, Brasil \\ ${ }^{2}$ Programa de Pós-graduação em Fisiologia, Universidade Federal do Rio Grande do Sul, Porto Alegre, RS, Brasil \\ ${ }^{3}$ Programa de Pós-graduação em Engenharia de Minas, Metalúrgica e de Materiais, Universidade Federal do Rio Grande do Sul, \\ Porto Alegre, RS, Brasil \\ ${ }^{4}$ Programa de Gradução em Odontologia, Universidade Luterana do Brasil, Canoas, RS, Brasil \\ ${ }^{5}$ Instituto de Pesquisa com Células Tronco, Porto Alegre, RS, Brasil
}

\begin{abstract}
Because bone-associated diseases are increasing, a variety of tissue engineering approaches with bone regeneration purposes have been proposed over the last years. Bone tissue provides a number of important physiological and structural functions in the human body, being essential for hematopoietic maintenance and for providing support and protection of vital organs. Therefore, efforts to develop the ideal scaffold which is able to guide the bone regeneration processes is a relevant target for tissue engineering researchers. Several techniques have been used for scaffolding approaches, such as diverse types of biomaterials. On the other hand, metallic biomaterials are widely used as support devices in dentistry and orthopedics, constituting an important complement for the scaffolds. Hence, the aim of this review is to provide an overview of the degradable biomaterials and metal biomaterials proposed for bone regeneration in the orthopedic and dentistry fields in the last years.
\end{abstract}

Key words: Bone regeneration; Tissue scaffolds; Biomaterials; Dentistry; Orthopedics; Metals

\section{Introduction}

Tissue engineering is proving to be a promising field. It consists of the association of cells, biomaterials, and bioactive factors in order to mimic the native tissue, aiming to restore, maintain, or improve tissue function. Bone tissue engineering aims to develop three-dimensional scaffolds to provide the necessary structural support for the formation of a new bone structure, where usually the addition of growth factors and cells contributes to the acceleration of the osteogenic lineage induction.

Bone tissue, when intact, performs critical functions for the human body. It is directly related to locomotion because of the mechanical support that it provides for the body. In addition, bone is responsible for maintaining mineral homeostasis and because of its rigidity, it is the foremost protective barrier of vital organs. As a result of being an active multifunctional tissue, bones are susceptible to injury, which could compromise their function.

Orthopedic and dental bone defects are common problems that can occur due to trauma, infections, neoplasms, congenital conditions, or simply by aging. Therefore, grafts are necessary to replace injured tissue, ensuring a close connection between the implant and the host bone. The materials used in this process must provide an ideal structural environment for cells that participate in the bone healing process.

Autogenous bone is considered the "gold standard" for bone regeneration due to its osteogenic, osteoconductive, and osteoinductive properties. However, its use depends on bone availability, with disadvantages such as the risk of vascular-nervous lesions and morbidity in the recipient bed, thereby limiting its use (1). A less invasive alternative are xenogenic, allogeneic, and alloplastic bone grafts.

The restrictions of xenogenous grafts are their limited capacity to be fully incorporated into the native bone, being present in the implanted area for long periods of time, in addition to the risk of rejection or disease transmission. Allogeneic bone exhibits reduced osteoinductive properties and such grafts have a risk of immunoreactions and transmission of infections (2).

Alloplastic biomaterials have been widely studied in tissue engineering including ceramics, polymers, and metals

Correspondence: J. Girón: <julianagironb@gmail.com>

Received February 8, 2021 | Accepted April 23, 2021 


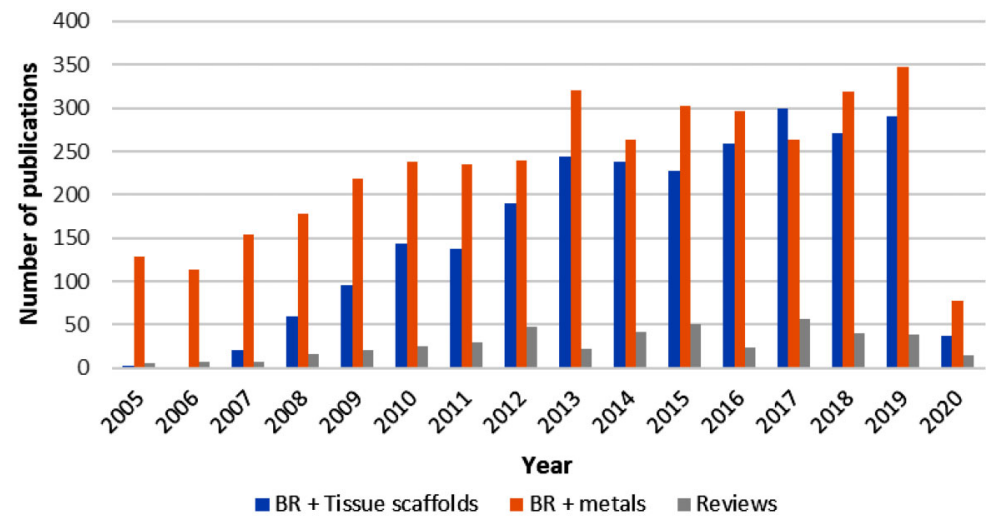

Figure 1. The number of annual publications in the PubMed database from 2005 to May 2020 using the terms: (Bone Regeneration [MeSH Terms]), (Tissue Scaffolds[MeSH Terms]) and (Metals). November 16, 2020. BR: bone regeneration.

and these materials can be associated with growth factors or cells. This type of graft has been investigated due to its advantages such as easy handling, great availability of shapes and sizes, and a high variety of resources for its production. In addition, the use of alloplastic biomaterials contributes to the reduction of surgical morbidity, absence of antigenicity, and risk of disease transmission (3).

Research studies involving the development of scaffolds for bone regeneration have increased considerably over the last fifteen years, and since 2013 , the number of publications has remained between 200 and 299 per year, as can be seen in Figure 1. The number of publications related to metals and bone regeneration has also been high over the years, but since 2014, the number of publications involving scaffolds is comparable to that of metals.

Currently, there are several techniques in tissue engineering used to develop scaffolds with different purposes. Some of these techniques are solvent casting, particulate leaching, freeze-drying, gas foaming, powderforming, sol-gel technique, electrospinning, and 3D printing. For metal biomaterials, the efforts are focused on surface treatment to promote osseointegration.

The aim of this review was to provide an overview of the biomaterials proposed for bone regeneration in the orthopedic and dentistry fields in the last years. This review focuses mainly on degradable biomaterials, without disregarding the important role of metals in orthopedics and dentistry.

\section{Degradable biomaterials for bone regeneration in orthopedics}

Orthopedic regenerative medicine aims to design bone scaffolds and implants able to replicate the biomechanical properties of the host bone. For bone regeneration, a scaffold should be biodegradable and biocompatible, as well as having osteoconductive, osteoinductive, and osteogenic properties (4). In addition, it is desirable that it

- Freeze Drying
- Electrospinning
- Three-Dimensional
Printing
- Solvent casting
- Sol-gel
- Gas foaming
= Particulate leaching

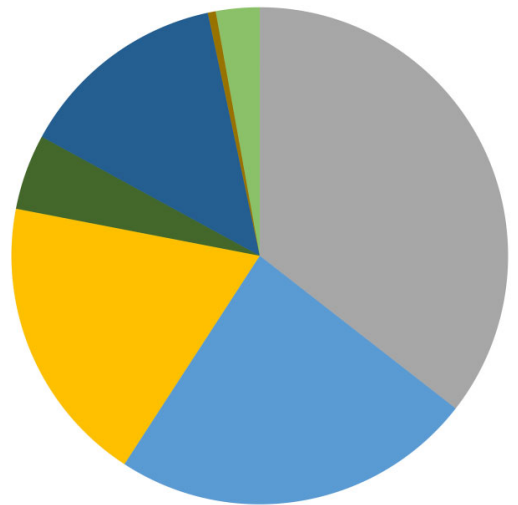

Figure 2. Distribution of manufacturing techniques cited for scaffolds with a bone regeneration objective. Each term has been associated with AND "Bone Regeneration"[MeSH]. June 1, 2020.

provides an appropriate exchange of nutrients, promotes vascularization and bone ingrowth, and has a pore size ranging from 100 to $500 \mu \mathrm{m}$ (5).

\section{Manufacturing techniques for bone scaffolds}

Figure 2 shows that in the last 10 years the most cited technique for the development of bone tissue regeneration scaffolds has been freeze-drying, followed by electrospinning, three-dimensional printing, and particulate leaching.

Three-dimensional printing, also known as additive manufacturing, is a technology that has been widely used in bone tissue engineering. It is a fast and strict process that consists of depositing materials layer by layer to produce 3D objects (6). The printed porous scaffold can have controlled parameters, being able to increase the reproducibility of the structure.

Recently, the development of three-dimensional scaffolds based on laser-cutting manufacturing process has been proposed (7). This technique consists of the generation of sheet-based scaffolds in which single sheets 
are manufactured and cut by a high precision laser that uses templates generated by computer-aided design (CAD). The sheets are then stacked to form a 3D scaffold. The advantages of this technique are that single sheets can be seeded with cells before being stacked, allowing for a spatially uniform cell distribution, as an appropriate cell distribution is difficult to obtain with solid scaffolds.

Using the solvent casting-particulate leaching method, highly porous scaffolds with good interconnections between each pore can be formed, but it can only be used to produce thin membranes of 3-4 $\mathrm{mm}$. This process consists of the mixture of a polymer solution and salt crystals with specific dimensions, followed by evaporation of the organic solvent. The remaining salt particles with the polymer matrix are then leached out by immersion in water, which dissolves the particles and produces a porous structure (8).

Freeze-drying is another technique used to manufacture high porosity polymeric scaffolds in which the polymer solution is frozen, leading to the solidification of the organic solvent that will be later removed by sublimation. Concentration of the polymer solution and the freezing temperature can influence the distribution of the pores and the pore size, enabling the creation of a wide variety of scaffolds with different pore structures (9). As a result, a 3D structure with interconnected pores is developed, although it has low mechanical stability and requires the use of toxic solvents.

Fibrous scaffolds provide a similar architecture to that of the extracellular matrix. Electrospinning is a method that creates an electrically charged jet of a polymer solution through a high voltage system, producing fibers with a thin diameter and a large surface area (10). Natural and synthetic polymers are used to fabricate the nanofiber structure, creating a three-dimensional environment that could be beneficial for cell attachment and proliferation. However, with the electrospinning technique, small pores are formed, and the porogen technique is not an option for larger structures as porogens need to be totally removed (7).

Three-dimensional printing can also be associated with other techniques, such as freeze-drying, to enhance the mechanical properties and biocompatibility of the scaffold. Kankala and colleagues elaborated a poly (lactide-co-glycolide) (PLGA) scaffold using the extrusion $3 \mathrm{D}$ printing technique and immersed it in a gelatin/nanohydroxyapatite solution (11). The scaffolds were frozen and lyophilized, resulting in a more hydrophilic scaffold with enhanced mechanical properties and biocompatibility, as well as presenting an increased level of alkaline phosphatase activity and higher osteocalcin content. Their study exemplifies an ingenious association of techniques and polymers to achieve a functional scaffold.

\section{Composition of bone regeneration scaffolds}

In regard to biomaterials composition, Figure 3 shows that in the last 10 years, collagen was the most cited polymer for the development of bone tissue regeneration scaffolds, followed by gelatin, chitosan, PLGA, polycaprolactone, alginates, hyaluronic acid, and polyvinyls. In the case of ceramics, Figure 4 shows that hydroxyapatite (HA) was the most cited ceramic in studies related to bone regeneration, followed by calcium phosphate $(\mathrm{CaP})$, and glass.

Bioactive ceramics and polymers can be classified as biomaterials due to their compatibility with living tissue. Furthermore, natural and synthetic ceramics are resistant to corrosion and can stimulate new bone formation but are very fragile and have low abrasion resistance. Ceramic biomaterials can include bioactive glasses, HA, calcium

\section{- Chitosan \\ m Collagen \\ m Gelatin \\ - Alginates \\ - Hyaluronic Acid \\ - Polycaprolactone \\ - Polyvinyls \\ ॥ Poly(lactic-co-glycolic acid)}

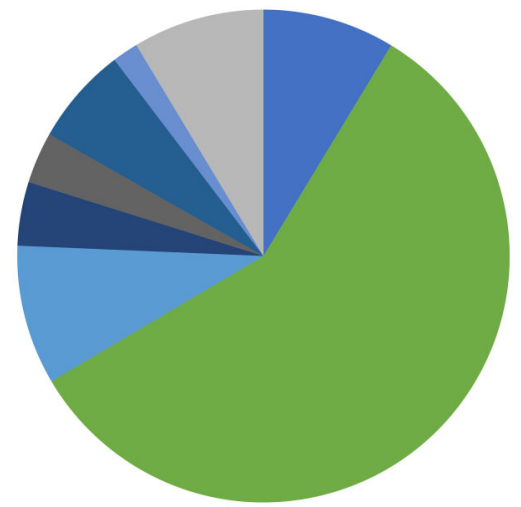

Figure 3. Graph showing polymer distribution in publications retrieved from a search in the PubMed database with the terms: "Chitin"[MeSH], "Collagen"[MeSH], "Gelatin"[MeSH], "Alginates" [MeSH], "Hyaluronic Acid"[MeSH], "Polycaprolactone" [Supplementary Concept], "Polyvinyls"[MeSH], "Polylactic Acid-Polyglycolic Acid Copolymer"[MeSH]. Each term has been associated with AND “Bone Regeneration” [MeSH]. June 1, 2020.

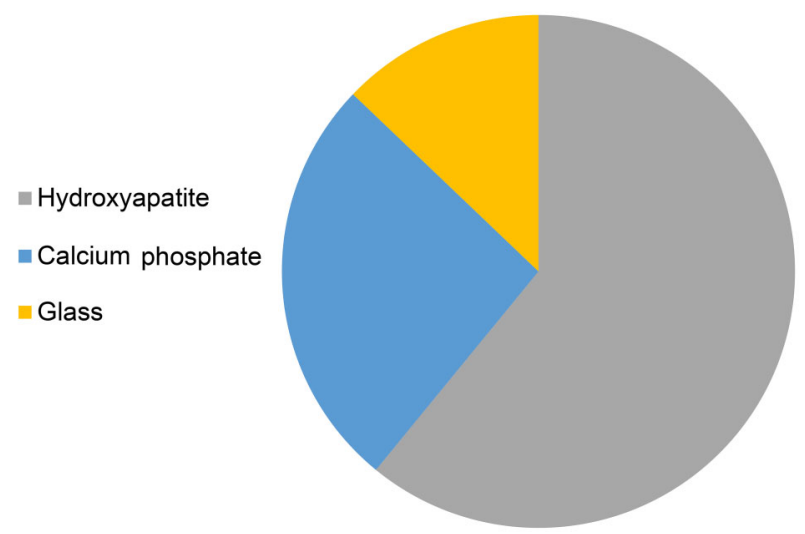

Figure 4. Graph showing ceramic distribution in publications retrieved from a search in the PubMed database using the following terms: "Hydroxyapatites"[MeSH], "Calcium Phosphate" [MeSH], "Glass"]MeSH]. Each term has been associated with AND “Bone Regeneration" [MeSH]. June 1, 2020. 
silicon, $\beta$-tricalcium phosphate $(\beta$-TCP), and biphasic calcium phosphate (BCP) (12).

Calcium phosphate-based ceramics are widely used for the fabrication of scaffolds for bone tissue engineering as calcium phosphate is abundant in native human bone. $\mathrm{HA}$ is the most frequently used bioceramic in the orthopedic field because of its excellent biocompatibility and osteoconduction properties (13). TCP is also commonly used in this field because it promotes proliferation of osteoprecursor cells. This biomaterial has less stability than HA and shows a faster degradation process and higher solubility (14).

Besides the inorganic matrix, bone is mostly composed of collagen. Therefore, many researchers have used collagen scaffolds for bone regeneration purposes. Collagen can provide a three-dimensional environment, which mimics some bone-forming components and can also increase cell proliferation. It can be associated with other biomaterials, such as bioceramics, carbon, and polymers in order to improve mechanical strength and bone repair (15). Calabrese and collaborators showed in their study that collagen associated with magnesium-enriched HA was beneficial for osteogenic differentiation (16).

Synthetic polymers are also widely utilized to produce scaffolds. In the orthopedics, some of the most common ones are poly $\epsilon$-caprolactone (PCL), polyglycolic acid (PGA), poly(lactide) (PLA), and PLGA. In addition to their biodegradability, the physicochemical and mechanical properties are comparable to native bone tissue. They can also be easily modified to obtain desired properties for different applications. In the research conducted by Lee and collaborators, PCL and PLGA were associated with TCP and a ceramic material made of sintered and ground duck beak. The study shows that the bone volume percentage of the PCL/PLGA/TCP and PCL/PLGA/duck beak scaffold groups is significantly higher than those of the control groups (17).

In recent years, there has been a growing interest in metal ions for bone scaffold purposes due to their biodegradability and biocompatibility, besides having important roles in tissues physiology. Magnesium (Mg-), iron (Fe), zinc, and their alloys have been the most studied. $\mathrm{Wu}$ et al. (18) proposed a three-dimensional composite scaffold with $\mathrm{HA}$ and magnesium oxide embedded in fiber of silkworm cocoon and silk fibroin. The addition of $1 \mathrm{wt} \%$ $\mathrm{MgO}$ led to the release of magnesium ions, which created a weak alkaline environment that improved the proliferation and osteogenic differentiation of bone marrow stem cells (BMSCs) in vitro, as well as promoted in vivo bone formation. The authors found that a $\mathrm{pH}$ between 7.2-8.5 could promote the proliferation of the BMSCs. On the other hand, zinc incorporation in a synthetic hydrogelamorphous calcium phosphate composite resulted in a significant increase of extracellular matrix mineralization after 21 days of BMSC culture in a study conducted by Chahal et al. (19).
A summary of the relevant studies in the last ten years is presented in Table $1(11,17,20-28)$. To elaborate this table, a search in the PubMed database was performed with the formula: (("Bone Regeneration"[MeSH]) AND "Tissue Scaffolds"[MeSH]) AND "Orthopedic Procedures"[MeSH]. The search with the 10-year filter resulted in 147 articles (29 reviews).

\section{Animal models}

Numerous in vivo experiments have been conducted in order to prove the effectiveness of the association of scaffolds and stem cells. The analyzed studies in Table 1 demonstrated that rabbits and rats are the most common animals tested in the orthopedic field. In the study carried out by Wang and collaborators (20), rabbits were used as animal models for treating bone defects in the femur. They proposed an association of $\beta$-TCP ceramic scaffold and mesenchymal stem cells (MSC). When the femoral vascular bundle was fixed into the side groove of the scaffold seeded with MSC, a higher new bone formation percentage and better vascularization were seen. Li et al. (21) followed the same strategy with the same animal model but combining the stem cells with different biomaterials and bone morphogenetic proteins (BMP-2), increasing new bone formation. Femoral defects were also conducted in rats, as shown in the study by Johnson and collaborators (29) using polycaprolactone/collagen/heparin scaffolds with the incorporation of BMP-2. Radial bone defect model in rabbits and rat calvaria defect are also frequently used. In vivo studies with sheep and pigs are still found although less frequently.

\section{Clinical trials}

Synthetic scaffolds based on HA and $\beta$ TCP have been the most used in clinical studies in orthopedics. Jäger and collaborators investigated the potency of bone marrow aspiration concentrate (BMAC) to augment bone grafting and support bone healing in local bone defects with a defect area (length $\times$ width) measurement larger than $1 \times 1 \mathrm{~cm}$. The BMAC was mixed with porous hydroxyapatite granules (Orthoss $\left.{ }^{\mathbb{R}}\right)(n=27)$ or applied onto a collagen sponge (Gelaspon $\left.{ }^{\mathbb{}}\right) \quad(n=12)$. The results show that BMAC-HA has complete bone healing faster than the group of BMAC-collagen and also that the postoperative bone formation appeared earlier in the HA group (30).

In 2016, Šponer et al. (31) reported a prospective, controlled clinical trial $(n=9)$ utilizing expanded autologous MSCs on a ultraporous $\beta$ tricalcium phosphate synthetic graft material $\left(\right.$ Vitoss ${ }^{\circledR}$ ) for femoral defects. The association of the $\beta$ TCP with MSCs increased the trabecula and decreased the radiolucency within the defect. Later in 2018, Šponer et al. (32) reported a prospective study, this time with 19 patients for the MSCs/ $\beta$ TCP group and using a control group treated with cancellous allografts. No significant difference was observed between femoral defect healing in the MSCs/ $\beta$ TCP group and the 
Table 1. Summary of relevant studies involving scaffolds for bone regeneration in the orthopedic field in the last ten years.

\begin{tabular}{|c|c|c|c|c|c|c|}
\hline $\begin{array}{l}\text { Reference, } \\
\text { year }\end{array}$ & Scaffold & Cells & Additive & $\begin{array}{l}\text { Manufacturing } \\
\text { technique }\end{array}$ & Study type & Results \\
\hline (20) 2010 & $\beta-\mathrm{TCP}$ & BMSCs & - & - & $\begin{array}{l}\text { Femur defects in } \\
\text { rabbits }(n=64)\end{array}$ & $\begin{array}{l}\text { Prevascularized tissue-engineered bone } \\
\text { grafts led to significantly higher volume of } \\
\text { regenerated bone and larger amount of } \\
\text { capillary infiltration }\end{array}$ \\
\hline (22) 2011 & $\mathrm{PCL} / \mathrm{TCP}$ & BMSCs & BMP-2 & Fused deposition & $\begin{array}{l}\text { Anterior lumbar } \\
\text { interbody fusion } \\
\text { - in Yorkshire } \\
\text { pigs }(n=6)\end{array}$ & $\begin{array}{l}\text { Solid fusion in PCL/TCP/BMP-2 group } \\
\text { comparable to autograft bone }\end{array}$ \\
\hline (23) 2013 & HA Sintlife, Engipore & MSCs & - & Slurry expansion & In vitro & $\begin{array}{l}\text { Non-stoichiometric } \mathrm{MG}(2+) \text { and } \\
\text { stoichiometric apatites, in granular form, } \\
\text { represent a more favorable environment for } \\
\text { the growth of cells compared to a non- } \\
\text { stoichiometric } \mathrm{Mg}(2+) \text { apatite, in } \\
\text { nanostructured paste. }\end{array}$ \\
\hline (24) 2014 & $\begin{array}{l}\text { Cortical part: Silicon } \\
\text { carbide (BioSiC)/Collagen/ } \\
\text { HA Spongy-like part: Bio- } \\
\text { hybrid HA/collagen }\end{array}$ & BMSCs & PRP & $\begin{array}{l}\text { Electrodeposition } \\
\text { of collagen, } \\
\text { freeze drying }\end{array}$ & $\begin{array}{l}\text { Study in sheep } \\
\text { with diaphyseal } \\
\text { defects }(n=5)\end{array}$ & $\begin{array}{l}\text { PRP or BMSCs did not further improve } \\
\text { the osteotomy healing. Significantly } \\
\text { higher values in periosteal callus score } \\
\text { in the BioSiC }(\mathrm{HaCol})+\mathrm{BMSC} \text { group }\end{array}$ \\
\hline (25) 2014 & $\beta-\mathrm{TCP}$ & Osteoblastic cells & - & $\begin{array}{l}\text { Rapid prototyping } \\
\text { (RP) } 3 \mathrm{D}\end{array}$ & $\begin{array}{l}\text { Rabbit radius } \\
\text { defects }(n=3)\end{array}$ & $\begin{array}{l}\text { Scaffolds constructed by perfusion seeding } \\
\text { and perfusion culture method exhibited } \\
\text { better biological properties, significantly } \\
\text { higher new bone formation and greater } \\
\text { mechanical properties. }\end{array}$ \\
\hline 2015 & Bioactive glass & - & - & $\begin{array}{l}\text { Melting and } \\
\text { homemade fiber } \\
\text { tower }\end{array}$ & $\begin{array}{l}\text { Study in rat with } \\
\text { tibial defect } \\
(n=10)\end{array}$ & $\begin{array}{l}\text { Similar amount of newly formed bone } \\
\text { compared with the control group and } \\
\text { enhanced expression of RUNX-2 and } \\
\text { RANK-L }\end{array}$ \\
\hline (17) 2016 & $\begin{array}{c}\text { PCL/PLGA/TCP, PCL/ } \\
\text { PLGA/sintered and ground } \\
\text { duck beak }\end{array}$ & - & - & $\begin{array}{c}\text { Multi-head } \\
\text { deposition system }\end{array}$ & $\begin{array}{l}\text { Study in } \\
\text { rabbit with } \\
\text { diaphysis } \\
\text { defect }(n=4)\end{array}$ & $\begin{array}{c}\text { Bone volume percentage of the PCL/PLGA/ } \\
\text { TCP and PCL/PLGA/duck beak scaffold } \\
\text { groups was significantly higher compared } \\
\text { to the control group. }\end{array}$ \\
\hline 2017 & $\begin{array}{l}\text { Pullulan/dextran-based } \\
\text { hydrogel and HA/TCP } \\
\text { ceramics }\end{array}$ & BMSCs & - & - & $\begin{array}{l}\text { Study in rat } \\
\text { with femoral } \\
\text { defect }(n=10)\end{array}$ & $\begin{array}{c}\text { The hydrogel showed significant osteogenic } \\
\text { properties and rapid resorption. }\end{array}$ \\
\hline (21) 2018 & $\begin{array}{l}\text { Lithium (Li)-nanoHA/ } \\
\text { gelatin microsphere (GM) }\end{array}$ & $\begin{array}{l}\text { BMSCs and } \\
\text { human umbilical } \\
\text { vein endothelial } \\
\text { cells (HUVECs) }\end{array}$ & $\begin{array}{l}\text { Erythrogenin } \\
\qquad(E P O)\end{array}$ & Freeze drying & $\begin{array}{l}\text { Study in rabbit } \\
\text { with femoral } \\
\text { head defect } \\
\quad(n=15)\end{array}$ & $\begin{array}{l}\text { The scaffold was able to improve new } \\
\text { bone formation, increasing cell proliferation } \\
\text { and osteogenesis, and angiogenesis effects. }\end{array}$ \\
\hline (28) 2019 & $\begin{array}{l}\text { Hyperelastic bone (HA and } \\
\text { PLGA) }\end{array}$ & - & - & $\begin{array}{l}\text { 3D printing and } \\
\text { salt-leaching } \\
\text { technique }\end{array}$ & $\begin{array}{l}\text { Study in rat } \\
\text { with calvaria } \\
\text { defect }(n=10)\end{array}$ & $\begin{array}{l}\text { New bone formation surrounding the scaffold } \\
\text { struts by } 12 \text { weeks. }\end{array}$ \\
\hline 2020 & $\begin{array}{l}\text { Gelatin/nano- } \\
\text { hydroxyapatite/ and poly } \\
\text { (lactide-co-glycolide) }\end{array}$ & $\begin{array}{l}\text { Osteoblasts } \\
\text { (MC3T3-E1) }\end{array}$ & & $\begin{array}{l}\text { 3D printing and } \\
\text { freeze-drying }\end{array}$ & In vitro & $\begin{array}{l}\text { Enhanced hydrophilicity, mechanical } \\
\text { properties and biocompatibility. Increased } \\
\text { level of alkaline phosphatase activity. Higher } \\
\text { osteocalcin content. Promotion of the } \\
\text { secretion of collagen I. }\end{array}$ \\
\hline
\end{tabular}

$\beta$-TCP: $\beta$-tricalcium phosphate; BMSCs: bone marrow stromal cells; PCL: polycaprolactone; PLGA: poly(lactic-co-glycolic acid); BMP-2: bone morphogenetic protein 2; HA: hydroxyapatite; MSCs: mesenchymal stromal cells; PRP: platelet-rich plasma; RUNX-2: runt-related transcription factor 2; RANK-L: receptor activator of nuclear factor-kappa $\beta$ ligand; MC3T3-E1: osteoblastic cell line.

cancellous allograft group. However, significant differences were documented between the $\beta$ TCP group and the cancellous allograft group.
The use of scaffolds in the clinical field has shown good results for bone regeneration purposes; however, translational difficulties still exist and more clinical studies 
are necessary for the implementation of scaffolds in clinical practice.

\section{Degradable biomaterials for bone regeneration in dentistry}

Bone regeneration is one of the most important and challenging tissue engineering approaches in regenerative medicine, being a promising technique in dentistry as it is considered to be an ideal strategy for treating diseases, injuries, and defects within the maxillofacial region. More importantly, the principles of tissue engineering have been applied in several branches of dentistry, such as oral maxillofacial surgery, periodontics, and implant dentistry, with a wide variety of scaffolds available for purchase on the market.

Tooth extraction caused by periodontal disease or trauma, leading to alveolar bone loss are frequent problems that dentists have to deal with. Bone resorption of the residual ridge continues throughout life in edentulous patients, being difficult to restore the missing teeth with dental implants or prosthodontic approaches (33). In addition, the occurrence of defects in maxillofacial bones are common and can be caused by a range of factors such as infections, congenital deformities, trauma, or tumorectomy (34), which need to be treated for reposition of tissue and restoration of function of the patient. Therefore, tissue engineering techniques using scaffolds for bone regeneration have become a frontier in dentistry, looking towards the preservation of the periodontium and the different bone regions of the maxillofacial complex.

In Table 2, a summary of relevant studies related to scaffolds for bone regeneration in the dentistry field is presented (35-45). A search was performed in the PubMed database with the formula: (("Bone Regeneration" [MeSH]) AND "Tissue Scaffolds"[MeSH]) AND "Dentistry"[MeSH] on April 16, 2020 using the filter of the last ten years and not considering reviews.

As shown in Table 2, several biomaterials have been proposed for maxillofacial bone regeneration including synthetic polymers such as PCL, PLLA, and PLGA, calcium phosphate compounds such as $\beta T C P$, biphasic calcium phosphate $(\mathrm{HA} / \beta-\mathrm{TCP})$, cyanoacrylate-combined calcium phosphate (CCP), and $\mathrm{HA}$ and its compounds such as MgHA or n-HA/PA. Natural polymers have also been proposed such as collagen, hyaluronic acid, PRF, ilk fibroin, gelatin, and chitosan, and even decellularized matrices such as cartilage matrix or demineralized bone matrix. However, only HA, TCP, inorganic bone matrix, and collagen scaffolds have been widely evaluated clinically as bone substitutes to date $(33,46)$.

$\mathrm{HA}$ and TCP ceramics have a chemical and biological similarity to bone tissue, providing good biocompatibility and cell adhesion properties. TCP is a resorbable biomaterial with a faster degradation rate than bone regeneration (47). It has therefore been necessary to improve its mechanical properties by the association with other biomaterials such as HA or PCL $(38,39,48)$. $\beta$-TCP releases calcium ions into local tissue, which contributes to the control of osteoblastic viability, proliferation, and differentiation (49), indicating that calcium phosphatebased materials present osteoconductivity properties.

A human clinical study with X-ray computed microtomography (microCT) and histomorphometric analysis of bone biopsies demonstrated that for sinus augmentation, 9 months after grafting a scaffold of HA/ $\beta$-TCP $30 / 70$ in granules or blocks, the block-based scaffold had a significantly higher strut thickness and strut number, closer to that of native healthy tissue (48). In addition, a large amount of newly formed bone and a rich net of new vessels was detected, which meant that not only the scaffold composition but also the scaffold morphology influences the quality of the regenerated tissue.

Although the sole implantation of scaffolds has brought good results, studies have shown that planting stem cells on scaffolds, previous to the implantation, contributes to bone deposition and angiogenic stimulation, which could be relevant in poor bone marrow sites such as the mandibular angle $(38,39,41,50)$. Additionally, in cases where dental implants are placed in junction with bone grafts, bone-implant contact has also improved with the addition of stem cells on the scaffold, contributing to primary stability of the dental implant $(49,51)$.

Growth factors like GDF-5, BMP-7, PDGF, and BMP-2 have also been incorporated onto scaffolds, improving therapeutic potential and increasing the percentage of the regenerated bone area $(36,37,52)$.

Despite the latest technological advances achieved in bone tissue scaffolds, autogenous bone is still the gold standard in dentistry, but limitations related to bioavailability and morbidity makes continuous research necessary in order to develop a scaffold resembling the autogenous bone matrix. However, Bayat and collaborators used BMG to regenerate alveolar osseous defects in cats, showing new bone formation and mineralization superior to autogenous bone at day 56 (35). Additionally, the use of calcium phosphate cement with the addition of cryopreserved bone-derived osteoblasts has shown results comparable to that of autogenous bone.

As in orthopedisc, three-dimensional printing in dentistry has assumed important relevance. It has many advantages such as the possibility of direct printing in the defective site, which means a faster scaffold preparation with increased accuracy. It also allows the production of scaffolds with different intricate shapes resembling the lesion.

Recently, Lopez and collaborators developed a threedimensionally printed bioactive ceramic scaffold of $\beta$-TCP coated with dipyridamole, an adenosine A2A receptor indirect agonist, which could inhibit osteoclastogenesis. They created a critical-size bone defect at the mandibular rami of rabbits. Bone growth was evaluated by microCT. 
Table 2. Summary of relevant studies involving scaffolds for bone regeneration in the dentistry field in the last ten years.

\begin{tabular}{|c|c|c|c|c|c|c|}
\hline $\begin{array}{l}\text { Reference, } \\
\text { year }\end{array}$ & Scaffold & Cells & Additive & $\begin{array}{l}\text { Manufacturing } \\
\text { technique }\end{array}$ & Study type & Results \\
\hline (35) 2010 & $\begin{array}{l}\text { BMG (bone matrix gelatin) } \times \\
\text { autogenous bone graft }\end{array}$ & - & - & Freeze-drying & $\begin{array}{l}\text { Study in cats with } \\
\text { alveolar osseous } \\
\text { defects }(n=4) \text {. }\end{array}$ & $\begin{array}{l}\text { Greater levels of new formed bone in BMG group. } \\
\text { Only on day } 56, \text { the mean of bone density was } \\
\text { significantly higher in the BMG group. }\end{array}$ \\
\hline (36) 2011 & $\beta$-ТCP & 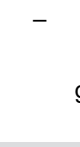 & $\begin{array}{l}\text { Platelet- } \\
\text { derived } \\
\text { growth factor } \\
\text { (PDGF) }\end{array}$ & 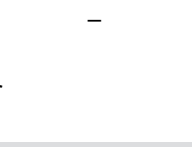 & $\begin{array}{l}\text { Clinical trial, } \\
\text { periodontal osseous } \\
\text { defects }(n=27) \text {. }\end{array}$ & $\begin{array}{l}\text { The linear bone growth and percentage of bone } \\
\text { filling were significantly higher in the PDGF } \\
+\beta \text {-TCP group at } 6 \text { months compared with that in } \\
\text { the } \beta \text {-TCP group. }\end{array}$ \\
\hline (37) 2012 & $\beta$-TCP & - & BMP-7 & - & $\begin{array}{l}\text { Study in rabbits with } \\
\text { osseo-periosteal } \\
\text { mandibular defect } \\
\quad(n=6) .\end{array}$ & $\begin{array}{l}\text { The overall mean of the percentage of } \\
\text { regenerated bone was considerably greater } \\
\text { when BMP-7 was incorporated. }\end{array}$ \\
\hline (38) 2013 & $\begin{array}{l}\text { PCL/TCP }(80: 20) \\
\text { (Osteopore) }\end{array}$ & BMSC & - & 3D printing & $\begin{array}{l}\text { Vertical alveolar } \\
\text { ridge defect in dogs' } \\
\text { mandible }(n=4) \text {. }\end{array}$ & $\begin{array}{l}\text { Early revascularization and higher amount of new } \\
\text { bone. }\end{array}$ \\
\hline (39) 2015 & $\begin{array}{l}\beta-\text { TCP and Type I } \\
\text { collagen }\end{array}$ & BMSC & - & (1) & $\begin{array}{l}\text { Study in beagle dogs } \\
\text { with class III } \\
\text { furcation defects } \\
\qquad(n=6) .\end{array}$ & $\begin{array}{l}\mathrm{BMSC} / \text { collagen and } \mathrm{BMSC} / \text { collagen/ } \beta-\mathrm{TCP} \\
\text { enhanced periodontal tissue regeneration } \\
\text { compared with collagen and } \beta \text {-CP/collagen. }\end{array}$ \\
\hline (40) 2015 & Magnesium/PLGA & - & - & $\begin{array}{l}\text { Solvent casting, } \\
\text { salt leaching }\end{array}$ & $\begin{array}{l}\text { Study in beagle dogs } \\
\text { with alveolar bone } \\
\text { defects }(n=6) \text {. }\end{array}$ & $\begin{array}{l}\text { S Mg provided pH buffering properties to the } \\
\text { scaffold, as well as an osteoconductive } \\
\text { environment for bone growth. }\end{array}$ \\
\hline (41) 2016 & $\begin{array}{l}\text { Chitosan/ } \beta \text {-glycero- } \\
\text { phosphate with } \\
\text { anorganic bovine bone }\end{array}$ & BMSC & - & Freeze-drying & $\begin{array}{l}\text { Study in beagle } \\
\text { dogs with bone } \\
\text { periodontal defects } \\
\quad(n=6) .\end{array}$ & $\begin{array}{l}\text { Highest new bone area value and new bone height } \\
\text { value compared with the control group. No } \\
\text { significant difference was shown with the } \\
\text { incorporation of the cells. }\end{array}$ \\
\hline (42) 2017 & $\begin{array}{l}\text { Fibronectin/decellularized pulp } \\
\text { tissue }\end{array}$ & - & - & $\begin{array}{l}\text { Decellularization } \\
\text { and } \\
\text { freeze-drying }\end{array}$ & $\begin{array}{l}\text { Study in rabbits with } \\
\text { calvaria defects } \\
\quad(n=12) .\end{array}$ & $\begin{array}{l}\text { Silk fibroin-coated scaffold demonstrated the } \\
\text { ability to induce new bone formation with low } \\
\text { inflammation and high vascularity. }\end{array}$ \\
\hline 2018 & $\begin{array}{c}\text { Nano-HA and collagen type I } \\
(1: 1)(\text { Allgens })+\text { Mg-Ca alloy } \\
\text { rods }\end{array}$ & - & - & $\begin{array}{l}\text { Three } \mathrm{Mg}-\mathrm{Ca} \\
\text { alloy rods were } \\
\text { inserted } \\
\text { into mineralized } \\
\text { collagen }\end{array}$ & $\begin{array}{l}\text { Study in dogs with } \\
\text { canine socket } \\
\text { preservation } \\
\text { model }(n=6) \text {. }\end{array}$ & $\begin{array}{l}\text { The combined scaffold of mineralized collagen/ } \\
\text { Mg-Ca alloy rods was more effective at reducing } \\
\text { the absorption of the alveolar ridge and preserving } \\
\text { the socket site than the mineralized collagen } \\
\text { alone. }\end{array}$ \\
\hline (44) 2019 & $\begin{array}{l}\text { Silica coated nanoHA-gelatin } \\
\text { reinforced and poly(L-lactic } \\
\text { acid) PLLA }\end{array}$ & - & - & $\begin{array}{l}\text { Electrospun } \\
\text { and chemical } \\
\text { synthesis route }\end{array}$ & $\begin{array}{l}\text { Study in rabbits } \\
\text { with bone defects } \\
\text { in the jaw }(n=12) \text {. }\end{array}$ & $\begin{array}{l}\text { The scaffold suffered degradation along with the } \\
\text { regeneration of new tissue. }\end{array}$ \\
\hline 2020 & $\begin{array}{l}\text { PCL/TCP-based ink and } \\
\text { methacrylate hyaluronic acid/ } \\
\text { methacrylate gelatin-based } \\
\text { bioink }\end{array}$ & - & $\begin{array}{l}\text { Resveratrol } \\
\quad \text { and } \\
\text { strontium } \\
\text { ranelate }\end{array}$ & 3D printing & $\begin{array}{l}\text { Study in rats with } \\
\text { critical-sized } \\
\text { mandibular bone } \\
\text { defect }(n=6) \text {. }\end{array}$ & $\begin{array}{l}\text { Enhanced angiogenesis and inhibition of } \\
\text { osteoclast activity. The scaffolds promoted MSC } \\
\text { osteogenic differentiation and bone formation }\end{array}$ \\
\hline
\end{tabular}

BMG: bone matrix gelatin; $\beta$-TCP: $\beta$-tricalcium phosphate; TCP: tricalcium phosphate PDGF: platelet-derived growth factor; BMSCs: bone marrow stromal cells; PCL: polycaprolactone; PLGA: poly(lactic-co-glycolic acid); PLLA: poly(L-lactic acid); BMP-7: bone morphogenetic protein 7; HA: hydroxyapatite; Mg: magnesium; Ca: calcium.

The results showed a larger percentage of bone in the dipyridamole group, which means that incorporation of dipyridamole increased the bioactivity of the scaffold (53).

\section{Commercially available scaffolds}

The collagen membranes type I or III from porcine or bovine origin have been widely used for guided bone regeneration, which consists of creating a barrier to prevent the migration of soft tissue cells into the bone graft. Without the presence of such a barrier, the cells could invade the environment for the new bone formation (50).

Analyzing the studies obtained after applying the same formula cited above (("Bone Regeneration"[MeSH]) AND "Tissue Scaffolds"[MeSH]) AND "Dentistry"[MeSH] on April 4, 2020) on the PubMed database, it was found that the composition of the majority of the scaffolds used in the studies was the natural polymer collagen, and 
commercially available scaffolds such as Olympus Terumo Biomaterials, Parasorb cone, Terudermis, Bio-Gide, CollaCote, $\mathrm{BD}^{\mathrm{TM}}$ 3D Collagen Composite Scaffold, and Mucograft were used. Also, tilapia type I collagen scaffold has been studied showing promising results (54). Additionally, hybrid bone substitutes based on hydroxyapatite/TCP were reported as Osteon II, Ceraform ${ }^{\circledR}$, and Reprobone.

Mineralized collagen has been studied due to its similarity to the natural bone microstructure because it is composed of nano-hydroxyapatite and collagen type I (1:1). To compensate mechanical limitations, three $\mathrm{Mg}-\mathrm{Ca}$ alloy rods were inserted into mineralized collagen, a strategy that allows for a successful overcoming of such a limitation (43).

For vertical fillings or socket filling, deproteinized bovine bone is the scaffold most frequently used due to its osteoconduction properties and bone neoformation capacity. Although it is not fully reabsorbed by the body, clinical success in regard to good structural support has been reported in the scientific literature (55). Bio-Oss is an example of this type of scaffold, being the commercial scaffold of choice for many bone regeneration procedures in dentistry. However, Mayer and collaborators demonstrated that a bioactive bovine bone (Alpha Bio's Graft) scaffold reinforced with $\mathrm{PCL}$ caused a higher percentage of new bone compared to Bio-Oss (56).

\section{Animal models}

Several animal model studies have been used to evaluate scaffolds in which cats, rabbits, rats, and dogs were used to develop various types of bone defects (Table 2). Bone defects frequently used in the dentistry field are alveolar osseous defects, peri-implant defects, periodontal osseous defects, dehiscence type defects in mandible, bone alveolar ridge defects, class III furcation defects, calvaria defects, maxillary sinus floor augmentation, and mandibular branch defects, which are the most frequent lesions that dentists have to deal with.

Scaffolds (BMG or magnesium/PLGA) without cells or growth factors successfully promoted new bone formation in models of alveolar bone defects in cats and dogs $(35,40)$ and also in models of peri-implantitis defects in rabbits (scaffold silk fibroin powder/PRF) (57). Furthermore, in a study using a periodontal defect model in dogs and a chitosan/ $\beta$-glycerophosphate scaffold, the incorporation of BMSC did not represent a significant increase in new bone area or new bone height (41), showing a similar performance compared with the group without cells.

\section{Clinical trials}

Clinical studies with humans have demonstrated that for bone regeneration of small bone defects, such as alveolar bone defects (58) or some sinus augmentations (48), the scaffold implantation is sufficient, without the need of cells or growth factors. However, the use of cells and growth factors could accelerate healing, as it is interesting to reduce the waiting time between the surgical-prosthetic steps (59). Rickert and collaborators showed that for maxillary sinus floor elevation, the incorporation of stem cells into a bovine bone mineral scaffold (BioOss ${ }^{\circledR}$ ) was a strategy as efficient as using BioOss ${ }^{\circledR}$ mixed with autogenous bone (46). Nevertheless, Chen et al. (60) showed that for periodontal defects, no statistically significant difference was detected when stem cells are incorporated into the BioOss ${ }^{\circledR}$ scaffold in a randomized clinical trial.

Jayakumar et al. (36) carried out a human clinical study, where patients presented periodontal osseous defects. Their strategy to gain bone volume was to incorporate PDGF into a scaffold of $\beta$-TCP. The results showed that linear bone growth and percent of bone filling were significantly higher in the PDGF-BB $+\beta$-TCP group at the end of 6 months, compared with that in the $\beta$-TCP group.

Since there is a range of possibilities of techniques and materials for the production of bone regeneration scaffolds, further studies are suggested with a higher number of patients and applying a randomization criterion. In addition, it is necessary to establish which type of cells and growth factors are more appropriate to be associated with scaffolds and also to establish the most appropriate technique for scaffold production according to the bone morphology and localization.

\section{Role of metallic biomaterials in orthopedics and dentistry}

Metallic biomaterials are widely used in orthopedics as support devices, being mainly utilized for the manufacture of plates, fixation screws, and orthopedic implants for the replacement of missing joints or bones. In the dentistry field, metallic biomaterials can be also used to manufacture dental implants as well as metallic meshes for the stabilization of bone grafts in guided bone regeneration. Its rigidity provides space maintenance and avoids collapse of the contour and displacement of the graft.

The success of a metallic implant in the human body is directly related to biocompatibility and reduced immune response. Despite the widespread use of metal implants, they have some disadvantages and although being biotolerable or bioinert, metal alloys can release particles due to wear or chemical degradation, which could cause different pathologies, requiring a posterior removal of the implant (61), and even stimulate the metabolic pathways of many cell types, including osteoclasts, osteoblasts, lymphocytes, macrophages, or fibroblasts (62). In addition, the failure of implants can occur due to the difference between the elastic modules of the metallic implants and the host tissue, causing the phenomenon known as "stress shielding" (63).

Among the metallic biomaterials, the use of silver, magnesium, cobalt, niobium, strontium, and titanium is becoming prominent for application in bone regeneration in 
dentistry and orthopedics. However, for support elements, titanium is the most commonly used (64) (Figure 5); among the titanium alloys, Ti6Al4V is the best known, being used in approximately $50 \%$ of the applications (65).

Titanium and its alloys are called "special metals" and are considered ideal for implants as they have satisfactory mechanical properties and resistance to corrosion. The latter property is normally conferred to these materials due to the occurrence of a spontaneous reaction with the formation of a passive layer of $\mathrm{TiO}_{2}$ on its surface, which acts as a protective barrier.

However, depending on the conditions of the medium, titanium and its alloys can corrode very quickly or slowly depending on the environment being anaerobic, where water is the oxidizing agent, or aerobic, where oxygen is the oxidizing agent. In the case of alloys, the thickness of this oxide layer becomes a critical parameter because it acts directly on controlling the release of metal ions $(66,67)$. If this layer is very thin, the release of these ions is gradually facilitated, and thus it becomes less protective. On the other hand, the thicker the layer is, the more likely is crack formation, which will eventually lead to a pronounced release (66). In extreme cases, corrosion can cause a reduction in the mechanical performance, or even fracture of the implant, reaching the surrounding tissue, and consequently, the need for implant removal (67).

In the specific case of Ti6Al4V, some in vivo studies have already shown the release of titanium ions by the dissolution of implanted devices (68). The dissolution of aluminum ( $\mathrm{Al}$ ) in the human organism can promote pathologies such as the Alzheimer's disease, peripheral neuropathy, and osteomalacia. In addition, the presence

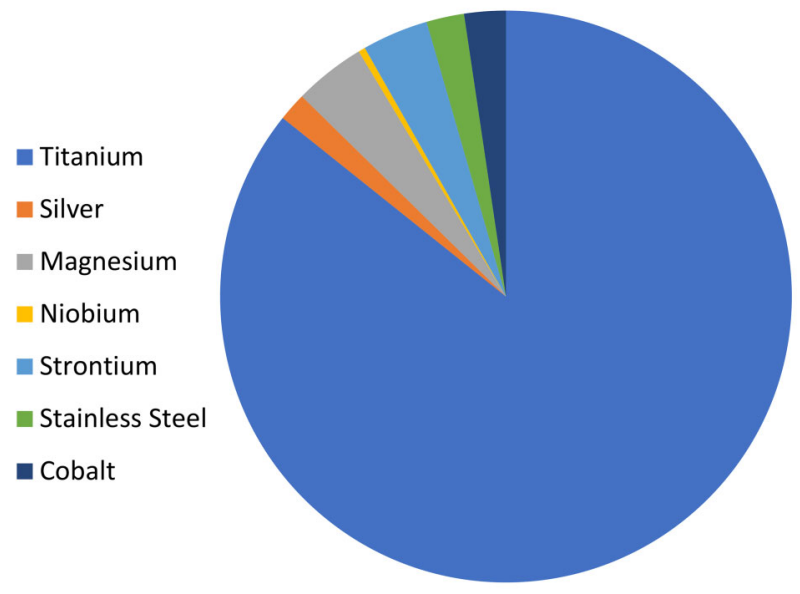

Figure 5. Graph showing metals distribution in publications retrieved from a search in the PubMed database using the following terms: "Titanium", "Silver", "Magnesium", "Niobium", "Strontium", "Stainless Steel" and "Cobalt". Each term has been associated with "AND "Bone Regeneration" [MeSH]. June 1, 2020 of vanadium $(\mathrm{V})$ can alter the kinetics of enzyme activity associated with the inflammatory response (69).

Another important factor in relation to titanium implants and their alloys is that their surfaces constitute an adequate environment for bacterial adhesion and proliferation, favoring the formation of biofilms that are largely inaccessible to the immune system and resistant to the action of drugs (70). Biofilm is a biological system layer that naturally develops from the adhesion of microorganisms to the surface; these biofilms are related to certain infectious diseases, and consequently to implant failure (71).

Qiao et al. (72) proposed a three-dimensional printed porous titanium alloy $\left(\mathrm{Ti}_{6} \mathrm{Al}_{4} \mathrm{~V}\right)$ embedded in an antibacterial hydrogel to prevent infections. The porous structure made the implant more compatible with host bone tissue, as it avoided stress-shielding and osteolysis. Furthermore, the implant system demonstrated effective antibacterial properties while inducing bone repair and osseointegration. This study shows that a non-degradable biomaterial can be associated with a degradable one to enhance tissue repair.

Therefore, the superficial modification of metallic implants is essential for improving their electrochemical performance, biocompatibility, and osseointegration process, with the aim of increasing their long-term stability as a biomaterial (73).

\section{Surface treatments}

Several processes to alter the surface characteristics of metallic implants in order to improve adaptation to bone tissue after implantation have been used.

The surface of metals can be modified with inorganic coatings such as CaP. These kinds of coatings allow for enhanced corrosion resistance, reduced metal ion release, and osteoblast attachment promotion. Oliveira and colleagues evaluated a nano-hydroxyapatite coated implant in diabetic rats, showing a statistically significant difference in gene expression of osteogenic markers Runx2, alkaline phosphatase, osteopontin, and osteocalcin in the early stage of osseointegration (74). Mokabber and colleagues developed a silver/calcium phosphate coating via electrochemical deposition on titanium substrates. The biomaterial showed bacterial reduction and excellent compatibility when silver ions were deposited as metallic silver nanoparticles on the CaP coating (75). Besides the CaP-based coatings, other inorganic coatings have been proposed such as glass ceramics, zeolites, and carbon, which possess great potential for bone tissue engineering.

Composite coatings have also been proposed to obtain enhanced bone regeneration properties, and they can usually be combined with inorganic coatings. Yu et al. (76) coated Ti-Al-4V substrates with collagen-HA composites, resulting in a slightly higher osteoblast proliferation rate compared with $\mathrm{HA}$ coating. 
Organic materials such as synthetic and natural polymers can be used as coatings for metallic implants. Polymers can prevent the corrosion of the implant, in addition to improving cell viability and adhesion. Also, polymer coatings could be used for the release of drugs that could contribute to the osseointegration of the implant. Therefore, anti-inflammatories have been proposed to prevent the aseptic loosening of orthopedic implants (77). Aseptic loosening is a frequent problem that occurs when particles are worn away from the implant surface and stimulate aseptic inflammatory responses for the phagocytosis of those small wear particles. Moreover, polymer coatings for the release of drugs that could support bone formation, such as alendronate and albumin, have been proposed (78).

On the other hand, the electrochemical treatments of electropolishing and anodizing, coatings obtained by plasma electrolytic oxidation, silane hybrid coatings by sol-gel, and plasma polymerization are prominent for application in the area of tissue regeneration.

In the electropolishing process, an anodic leveling and anodic brightening of the surface is made to reduce the roughness and improve the resistance to corrosion (79). This is considered an electrochemical process carried out through the use of the metallic substrate as a working electrode for polishing the metal (80). This process is performed using a voltage source that produces an electric current that passes from the anode to the cathode, resulting in the oxidation of the metal and removal of material from the surface at a controlled rate (81). The amount of the removed metal depends on the electrolyte, temperature, current density, and the metal to be electropolished (80).

The anodizing process aims to produce a stable oxide layer that is firmly adhered to the metal substrate. On titanium surfaces and their alloys, the formation of this layer normally occurs with a nanometric and selforganized topography as nanotubes, which has shown to be a promising strategy for biological and osseointegration processes (82). The main electrochemical parameters that affect the formation of these porous structures are $\mathrm{pH}$, voltage, temperature, and the presence of impurities in the material. The anodizing voltage itself mainly controls the diameter of the pore or tube. At the beginning of the electrochemical oxidation, the entire surface of the metal is covered with a compact and uniform anodic oxide, and following this, the layer begins to adsorb anions from the solution, promoting the formation and growth of the nanotubes (83).

The surface modification by plasma-assisted anodizing (PEO) treatment has been shown to be an innovative technology for the biomedical field (84). It is considered to be an electrochemical conversion treatment, which provides the superficial formation of a metallic oxide layer. It is a technique analogous to anodizing, but using higher values of current potentials and current densities, which causes a plasma formation on the sample surface. These coatings offer some advantages such as the adjustment of the elements incorporated into the metallic matrix and the control of the microstructure according to thickness and porosity (85).

Hybrid silane-based coatings combine organic and inorganic silicon-based functional groups, whose general formula is $\mathrm{R}^{\prime}(\mathrm{CH} 2) \mathrm{nSi}(\mathrm{OR}) 3$, where R' is an organofunctional group and $R$ is a hydrolyzable alkoxy group. When in contact with water, silanes are hydrolyzed to form silanol groups $(\mathrm{SiOH})$, which allow the bonding to the hydrated metal surface (metal-OH) via the formation of Si-O-metal bonds. The silanol groups undergo self-crosslinking through siloxane (Si-O-Si) bonds, resulting in an organic protection layer chemically bonded to the metallic substrate (86). Specifically, many of these coatings are being studied to improve the corrosion performance of metallic prostheses or to functionalize their surfaces through the incorporation of bioactive particles, biomolecules, drugs, and/or organic components dispersed in silane precursors $(70,87)$.

Another important application of silane coating in the biomedical field is the release of silicon compounds by hydrolytic degradation of the sol-gel network. The presence of the silicon element assists in the connective tissue metabolism of bone and cartilage and is associated with bone formation and calcification. In addition, silicon is involved in collagen type I synthesis and osteoblastic differentiation (88).

An advanced sol-gel technique is the application of hybrid silane coatings by the plasma polymerization technique, creating a film that protects the implant from corrosion, as it can be highly cross-linked and insoluble. The plasma can be used to chemically decompose the silane precursor and as a source of an active species to promote the formation of the film composition close to the used monomer (precursor) (89). Important advantages of this method are that it does not need toxic solvents, precursors do not necessarily need to present unsaturation to propagate the polymerization, and the adjustment of the parameters used in the plasma allows for the control of the properties of the resulting materials (thickness and chemical composition) (90). It is noteworthy that the use of alkoxysilane precursors stands out in this application method, mainly due to vaporization at room temperature, but some studies have been prioritizing the use of organoalkoxysilanes (89). In addition, thanks to easy thickness control, nanoscale coatings can be obtained, which consequently can favor protein interactions with bone cells and cell differentiation.

\section{Final considerations}

Despite the great advances in bone tissue engineering, the translation of innovative bone healing strategies to clinical applications still has a long way to go. 
The incorporation of cells has shown interesting results for bone tissue regeneration, but cell therapies are difficult to translate due to the complex regulatory barriers. Furthermore, the preparation of cells before implantation represents additional work, which is still not cost effective.

Currently, a large majority of studies have performed in vivo tests with smaller animals such as rats and rabbits, but testing these biomaterials in large animal models will be very important to analyze their effects more appropriately.

Furthermore, in the field of dentistry, in which irregularshaped critical-size defects are common in the craniofacial region, the 3D printing technique will be relevant, but the reduction of production costs will be necessary for clinical implementation.

Another relevant point to consider is that the microbial load in the oral cavity makes the development of scaffolds with antimicrobial function for the control of the infection and the promotion of bone formation critical.

Finally, since appropriate vascularization is indispensable for osteogenic differentiation, it is important to

\section{References}

1. Sobreira T, Maia FBM, Palitó APPG, Galdino AS, de Morai FR. Enxerto ósseo homógeno para reconstrução de maxila atrófica [in Portuguese]. Rev Cir Traumatol Buco Maxilo Fac 2011; 1 .

2. Dimitriou R, Jones E, McGonagle D, Giannoudis PV. Bone regeneration: current concepts and future directions. $B M C$ Med 2011; 9: 66, doi: 10.1186/1741-7015-9-66.

3. Rolvien T, Barvencik F, Klatte TO, Busse B, Hahn M, Rueger JM, et al. $\beta$-TCP bone substitutes in tibial plateau depression fractures. Knee 2017; 24: 1138-1145, doi: 10.1016/j.knee.2017.06.010.

4. Wagoner Johnson AJ, Herschler BA. A review of the mechanical behavior of $\mathrm{CaP}$ and $\mathrm{CaP} /$ polymer composites for applications in bone replacement and repair. Acta Biomater 2011; 7: 16-30, doi: 10.1016/j.actbio.2010.07.012.

5. Li L, Li Y, Yang L, Yu F, Zhang K, Jin J, et al. Polydopamine coating promotes early osteogenesis in $3 \mathrm{D}$ printing porous Ti6Al4V scaffolds. Ann Transl Med 2019; 7: 240, doi: 10.21037/atm.2019.04.79.

6. Ngo TD, Kashani A, Imbalzano G, Nguyen KTQ, Hui D. Additive manufacturing (3D printing): a review of materials, methods, applications and challenges.Composites Part B: Engineering. Elsevier Ltd;2018. p 172-196, doi: 10.1016/ j.compositesb.2018.02.012.

7. Schmid J, Schwarz S, Fischer M, Sudhop S, ClausenSchaumann $H$, Schieker $M$, et al. A laser-cutting-based manufacturing process for the generation of three-dimensional scaffolds for tissue engineering using Polycaprolactone/Hydroxyapatite composite polymer. J Tissue Eng 2019; 10: 2041731419859157, doi: 10.1177/204173141985 9157.

8. Prasad A, Sankar MR, Katiyar V. State of art on solvent casting particulate leaching method for orthopedic scaffolds fabrication.In:Materials Today: Proceedings. Elsevier Ltd; 2017. p 898-907, doi: 10.1016/j.matpr.2017.01.101. continue working on scaffolds that allow for vascularization in order to obtain a fully mature bone.

With regard to metallic biomaterials, although there are various surface modification techniques, many are costly and difficult to execute, which limit their clinical translation. Thus, it is important to look for simple and cost-effective strategies to achieve osteoconductive surfaces that are also capable of inhibiting the formation of biofilms.

\section{Acknowledgments}

This work was supported by Coordenação de Aperfeiçoamento de Pessoal de Nível Superior (CAPES) for Ph.D. fellowship to J. Girón [Brazil, grant number 88882 . 439513/2019-01, 2019]; Conselho Nacional de Desenvolvimento Científico (CNPq) for MSc fellowship to $\mathrm{T}$. Medeiros [Brazil, grant number 130799/20203]; CNPq for Postdoctoral fellowship to E. Kerstner [Brazil, grant number 155466/2018-6]; CNPq [Brazil, grant number 435539/2018-3].

9. Roseti L, Parisi V, Petretta M, Cavallo C, Desando G, Bartolotti I, et al. Scaffolds for bone tissue engineering: state of the art and new perspectives. Mater Sci Eng C Mater Biol Appl 2017; 78: 1246-1262, doi: 10.1016/j.msec. 2017.05.017.

10. Maurmann N, Sperling LE, Pranke P. Electrospun and Electrosprayed Scaffolds for Tissue Engineering. Adv Exp Med Biol 2018; 1078: 79-100, doi: 10.1007/978-981-130950-2.

11. Kankala RK, Xu XM, Liu CG, Chen AZ, Wang SB. 3D-printing of microfibrous porous scaffolds based on hybrid approaches for bone tissue engineering. Polymers (Basel) 2018; 10: 807, doi: 10.3390/polym10070807.

12. Zhu L, Luo D, Liu Y. Effect of the nano/microscale structure of biomaterial scaffolds on bone regeneration. Int $\mathrm{J}$ Oral Sci 2020; 12: 6, doi: 10.1038/s41368-020-0073-y.

13. Tripathi G, Basu B. A porous hydroxyapatite scaffold for bone tissue engineering: physico-mechanical and biological evaluations. Ceram Int 2012; 38: 341-349, doi: 10.1016/ j.ceramint.2011.07.012.

14. Jeong J, Kim JH, Shim JH, Hwang NS, Heo CY. Bioactive calcium phosphate materials and applications in bone regeneration. Biomater Res 2019; 23: 4, doi: 10.1186/ s40824-018-0149-3.

15. Zhang $\mathrm{D}, \mathrm{Wu} \mathrm{X}$, Chen J, Lin $\mathrm{K}$. The development of collagen based composite scaffolds for bone regeneration. Bioact Mater 2018; 3129-138, doi: 10.1016/j.bioactmat.2017.08.004.

16. Calabrese G, Giuffrida R, Forte S, Fabbi C, Figallo E, Salvatorelli $L$, et al. Human adipose-derived mesenchymal stem cells seeded into a collagen-hydroxyapatite scaffold promote bone augmentation after implantation in the mouse. Sci Rep 2017; 7: 7110, doi: 10.1038/s41598-01707672-0.

17. Lee JY, Son SJ, Son JS, Kang SS, Choi SH. Bone-healing capacity of PCL/PLGA/Duck beak scaffold in critical bone 
defects in a rabbit model. Biomed Res Int 2016; 2016: 136215, doi: 10.1155/2016/2136215.

18. Wu Z, Meng Z, Wu Q, Zeng D, Guo Z, Yao J, et al. Biomimetic and osteogenic 3D silk fibroin composite scaffolds with nano $\mathrm{MgO}$ and mineralized hydroxyapatite for bone regeneration. J Tissue Eng 2020; 11: 2041731422 0967791, doi: 10.1177/2041731420967791.

19. Chahal AS, Schweikle M, Lian AM, Reseland JE, Haugen $\mathrm{HJ}$, Tiainen $\mathrm{H}$. Osteogenic potential of poly(ethylene glycol)amorphous calcium phosphate composites on human mesenchymal stem cells. J Tissue Eng 2020; 11: 20417314 20926840, doi: 10.1177/2041731420926840.

20. Wang L, Fan H, Zhang ZY, Lou AJ, Pei GX, Jiang S, et al. Osteogenesis and angiogenesis of tissue-engineered bone constructed by prevascularized $\beta$-tricalcium phosphate scaffold and mesenchymal stem cells. Biomaterials 2010; 31: 9452-9461, doi: 10.1016/j.biomaterials.2010.08.036.

21. Li D, Xie X, Yang Z, Wang C, Wei Z, Kang P. Enhanced bone defect repairing effects in glucocorticoid-induced osteonecrosis of the femoral head using a porous nanolithium-hydroxyapatite/gelatin microsphere/erythropoietin composite scaffold. Biomater Sci 2018; 6: 519-537, doi: 10.1039/C7BM00975E.

22. Abbah SA, Lam CXF, Ramruttun AK, Goh JCH, Wong HK. Fusion performance of low-dose recombinant human bone morphogenetic protein 2 and bone marrow-derived multipotent stromal cells in biodegradable scaffolds: a comparative study in a large animal model of anterior lumbar interbody fusion. Spine (Phila Pa 1976) 2011; 36: 17521759, doi: 10.1097/BRS.0b013e31822576a4.

23. Manfrini M, Di Bona C, Canella A, Lucarelli E, Pellati A, D'Agostino $A$, et al. Mesenchymal stem cells from patients to assay bone graft substitutes. J Cell Physiol 2013; 228: 1229-1237, doi: 10.1002/jcp.24276.

24. Filardo $G$, Kon E, Tampieri A, Cabezas-Rodríguez R, Di Martino A, Fini M, et al. New bio-ceramization processes applied to vegetable hierarchical structures for bone regeneration: an experimental model in sheep. Tissue Eng Part $A$ 2014; 20: 763-773.

25. Wang L, Ma XY, Zhang Y, Feng YF, Li X, Hu YY, et al. Repair of segmental bone defect using totally vitalized tissue engineered bone graft by a combined perfusion seeding and culture system. PLoS One 2014; 9: e94276, doi: 10.1371/journal.pone.0094276.

26. Gabbai-Armelin PR, Souza MT, Kido HW, Tim CR, Bossini PS, Magri AMP, et al. Effect of a new bioactive fibrous glassy scaffold on bone repair. J Mater Sci Mater Med 2015; 26: 177, doi: 10.1007/s10856-015-5516-1.

27. Frasca S, Norol F, Le Visage C, Collombet JM, Letourneur $\mathrm{D}$, Holy $\mathrm{X}$, et al. Calcium-phosphate ceramics and polysaccharide-based hydrogel scaffolds combined with mesenchymal stem cell differently support bone repair in rats. J Mater Sci Mater Med 2017; 28: 35, doi: 10.1007/s10856016-5839-6.

28. Huang $Y H$, Jakus $A E$, Jordan $S W$, Dumanian $Z$, Parker $K$, Zhao L, et al. Three-dimensionally printed hyperelastic bone scaffolds accelerate bone regeneration in critical-size calvarial bone defects. Plast Reconstr Surg 2019; 143: 1397-1407, doi: 10.1097/PRS.0000000000005530.

29. Johnson MR, Boerckel JD, Dupont KM, Guldberg RE. Functional restoration of critically sized segmental defects with bone morphogenetic protein-2 and heparin treatment. Clin Orthop Relat Res 2011; 469: 3111-3117, doi: 10.1007/ s11999-011-2012-x.

30. Jäger $M$, Herten $M$, Fochtmann $U$, Fischer $J$, Hernigou $P$, Zilkens $C$, et al. Bridging the gap: bone marrow aspiration concentrate reduces autologous bone grafting in osseous defects. J Orthop Res 2011; 29: 173-180, doi: 10.1002/ jor.21230.

31. Šponer $P$, Filip Stanislav,Kucera T,Brtková J,Urban K, Palicka V,et al. Utilizing autologous multipotent mesenchymal stromal cells and $\beta$-tricalcium phosphate scaffold in human bone defects: a prospective, controlled feasibility trial. Biomed Res Int 2016; 2016: 2076061, doi: 10.1155/ 2016/2076061.

32. Šponer P, Kučera T, Brtková J, Urban K, Kočí Z, Měřička $P$, et al. Comparative study on the application of mesenchymal stromal cells combined with tricalcium phosphate scaffold into femoral bone defects. Cell Transplant 2018; 27: 14591468, doi: 10.1177/0963689718794918.

33. Messina AM, Marini L, Oh DS, Marini E. A Step-by-step procedure for bone regeneration using calcium phosphate scaffolds. J Craniofac Surg 2019; 30: 149-153, doi: 10.1097/ SCS.0000000000004996.

34. Zamiri B, Shahidi S, Eslaminejad MB, Khoshzaban A, Gholami M, Bahramnejad E, et al. Reconstruction of human mandibular continuity defects with allogenic scaffold and autologous marrow mesenchymal stem cells. J Craniofac Surg 2013; 24: 1292-1297, doi: 10.1097/SCS.0b013e3182 94288a.

35. Bayat M, Momen-Heravi F, Marjani M, Motahhary P. A comparison of bone reconstruction following application of bone matrix gelatin and autogenous bone grafts to alveolar defects: an animal study. J Craniomaxillofac Surg 2010; 38: 288-292, doi: 10.1016/j.jcms.2009.10.003.

36. Jayakumar A, Rajababu P, Rohini S, Butchibabu K, Naveen A, Reddy PK, et al. Multi-centre, randomized clinical trial on the efficacy and safety of recombinant human platelet-derived growth factor with $\beta$-tricalcium phosphate in human intra-osseous periodontal defects. J Clin Periodontol 2011; 38: 163-172, doi: 10.1111/j.1600-051X.2010. 01639.x.

37. Busuttil Naudi K, Ayoub A, McMahon J, Di Silvio L, Lappin $D$, Hunter KD, et al. Mandibular reconstruction in the rabbit using beta-tricalcium phosphate ( $\beta$-TCP) scaffolding and recombinant bone morphogenetic protein 7 (rhBMP-7) Histological, radiographic and mechanical evaluations. J Craniomaxillofac Surg 2012; 40: e461-e469, doi: 10.10 16/j.jcms.2012.03.005

38. Khojasteh A, Behnia H, Hosseini FS, Dehghan MM, Abbasnia P, Abbas FM. The effect of PCL-TCP scaffold loaded with mesenchymal stem cells on vertical bone augmentation in dog mandible: a preliminary report. J Biomed Mater Res B Appl Biomater 2013; 101: 848854, doi: $10.1002 / \mathrm{jbm}$.b.32889.

39. Nagahara T, Yoshimatsu S, Shiba H, Kawaguchi H, Takeda $\mathrm{K}$, Iwata $\mathrm{T}$, et al. Introduction of a mixture of $\beta$-tricalcium phosphate into a complex of bone marrow mesenchymal stem cells and type i collagen can augment the volume of alveolar bone without impairing cementum regeneration. J Periodontol 2015; 86: 456-464, doi: 10.1902/jop.2014. 140384. 
40. Brown A, Zaky S, Ray H, Sfeir C. Porous magnesium/PLGA composite scaffolds for enhanced bone regeneration following tooth extraction. Acta Biomater 2015; 11: 543-553, doi: 10.1016/j.actbio.2014.09.008.

41. Zang S, Jin L, Kang S, Hu X, Wang M, Wang J, et al. Periodontal wound healing by transplantation of jaw bone marrow-derived mesenchymal stem cells in chitosan/anorganic bovine bone carrier into one-wall infrabony defects in beagles. J Periodontol 2016; 87: 971-981, doi: 10.1902/ jop.2016.150504.

42. Thai TH, Nuntanaranont T, Kamolmatyakul S, Meesane J. In vivo evaluation of modified silk fibroin scaffolds with a mimicked microenvironment of fibronectin/decellularized pulp tissue for maxillofacial surgery. Biomed Mater 2017; 23: 015009, doi: 10.1088/1748-605X/aa853e.

43. Yu Q, Wang C, Yang J, Guo C, Zhang S. Mineralized collagen/Mg-Ca alloy combined scaffolds with improved biocompatibility for enhanced bone response following tooth extraction. Biomed Mater 2018; 13: 065008, doi: 10.1088/ 1748-605X/aadb47.

44. Manju V, lyer S, Menon D, Nair SV, Nair MB. Evaluation of osseointegration of staged or simultaneously placed dental implants with nanocomposite fibrous scaffolds in rabbit mandibular defect. Mater Sci Eng C Mater Biol Appl 2019; 104: 109864, doi: 10.1016/j.msec.2019.109864.

45. Zhang W, Shi W, Wu S, Kuss M, Jiang X, Untrauer JB, et al. 3D printed composite scaffolds with dual small molecule delivery for mandibular bone regeneration. Biofabrication 2020; 12:035020, doi: 10.1088/1758-5090/ab906e.

46. Rickert D, Sauerbier S, Nagursky H, Menne D, Vissink A, Raghoebar GM. Maxillary sinus floor elevation with bovine bone mineral combined with either autogenous bone or autogenous stem cells: a prospective randomized clinical trial. Clin Oral Implants Res 2011; 22: 251-258, doi: 10.1111/ j.1600-0501.2010.01981.x

47. Spaniol KG, Caldas SC, Peres APS, Dos Santos EA, Acchar W. $\beta$-TCP/PVA sheets crosslinked with citric acid produced via aqueous tape casting for bone regeneration. Ceram Int 2019; 45: 12417-12422, doi: 10.1016/j.cera mint.2019.03.173.

48. Giuliani A, Manescu A, Mohammadi S, Mazzoni S, Piattelli A, Mangano $F$, et al. Quantitative kinetics evaluation of blocks versus granules of biphasic calcium phosphate scaffolds (HA/ $\beta$-TCP $30 / 70)$ by synchrotron radiation $x$-ray microtomography: a human study. Implant Dent 2016; 25: 6-15, doi: 10.1097/ID.0000000000000363.

49. Maeno $S$, Niki $Y$, Matsumoto $H$, Morioka $H$, Yatabe $T$, Funayama A, et al. The effect of calcium ion concentration on osteoblast viability, proliferation and differentiation in monolayer and 3D culture. Biomaterials 2005; 26: 48474855, doi: 10.1016/j.biomaterials.2005.01.006.

50. Ribeiro FV, Suaid FF, Ruiz KGS, Rodrigues TL, Carvalho $\mathrm{MD}$, Nociti $\mathrm{FH}$, et al. Effect of autologous bone marrowderived cells associated with guided bone regeneration or not in the treatment of peri-implant defects. Int $J$ Oral Maxillofac Surg 2012; 41: 121-127, doi: 10.1016/j.ijom. 2011.06.025.

51. Han X, Liu H, Wang D, Su F, Zhang Y, Zhou W, et al. Alveolar bone regeneration around immediate implants using an injectable $\mathrm{nHAC/CSH}$ loaded with autogenic blood-acquired mesenchymal progenitor cells: an experimental study in the dog mandible. Clin Implant Dent Relat Res 2013; 15: 390-401, doi: 10.1111/j.1708-8208.2011.00373.x.

52. Chang $\mathrm{HC}$, Yang $\mathrm{C}$, Feng $\mathrm{F}$, Lin $\mathrm{FH}$, Wang $\mathrm{CH}$, Chang $\mathrm{PC}$. Bone morphogenetic protein-2 loaded poly(D,L-lactide-coglycolide) microspheres enhance osteogenic potential of gelatin/hydroxyapatite/ $\beta$-tricalcium phosphate cryogel composite for alveolar ridge augmentation. J Formos Med Assoc 2017; 116: 973-981, doi: 10.1016/j.jfma.2017.01.005

53. Lopez CD, Diaz-Siso JR, Witek L, Bekisz JM, Gil LF, Cronstein BN, et al. Dipyridamole augments three-dimensionally printed bioactive ceramic scaffolds to regenerate craniofacial bone. Plast Reconstr Surg 2019; 143: 14081419, doi: 10.1097/PRS.0000000000005531.

54. Hassanbhai AM, Lau CS, Wen F, Jayaraman P, Goh BT, Yu $\mathrm{N}$, et al. In vivo immune responses of cross-linked electrospun tilapia collagen membrane. Tissue Eng Part $A$ 2017; 23: 1110-1119, doi: 10.1089/ten.tea.2016.0504.

55. Avila-Ortiz G, Elangovan S, Kramer KWO, Blanchette D, Dawson DV. Effect of alveolar ridge preservation after tooth extraction: a systematic review and meta-analysis. J Dent Res 2014; 93: 950-958, doi: 10.1177/0022034514541127.

56. Mayer Y, Ginesin O, Khutaba A, Machtei EE, Zigdon Giladi $\mathrm{H}$. Biocompatibility and osteoconductivity of PLCL coated and noncoated xenografts: an in vitro and preclinical trial. Clin Implant Dent Relat Res 2018; 20: 294-299, doi: 10.1111/cid.12596.

57. Jang ES, Park JW, Kweon H, Lee KG, Kang SW, Baek DH, et al. Restoration of peri-implant defects in immediate implant installations by Choukroun platelet-rich fibrin and silk fibroin powder combination graft. Oral Surg Oral Med Oral Pathol Oral Radiol Endodontology 2010; 109: 831-836, doi: 10.1016/j.tripleo.2009.10.038.

58. Zhao L, Xu T, Hu W, Chung KH. Preservation and augmentation of molar extraction sites affected by severe bone defect due to advanced periodontitis: a prospective clinical trial. Clin Implant Dent Relat Res 2018; 20: 333-344, doi: 10.1111/cid.12585.

59. Al-Ahmady $\mathrm{HH}$, Abd Elazeem AF, Bellah Ahmed NE moataz, Shawkat WM, Elmasry M, Abdelrahman MA, et al. Combining autologous bone marrow mononuclear cells seeded on collagen sponge with Nano Hydroxyapatite, and platelet-rich fibrin: reporting a novel strategy for alveolar cleft bone regeneration. J Craniomaxillofacial Surg 2018; 46: 1593-1600, doi: 10.1016/j.jcms.2018.05.049.

60. Chen FM, Gao LN, Tian BM, Zhang XY, Zhang YJ, Dong GY, et al. Treatment of periodontal intrabony defects using autologous periodontal ligament stem cells: a randomized clinical trial. Stem Cell Res Ther 2016; 7: 33, doi: 10.1186/ s13287-016-0288-1.

61. Zhao J, Milanova M, Warmoeskerken MMCG, Dutschk V. Surface modification of $\mathrm{TiO} 2$ nanoparticles with silane coupling agents. Colloids Surfaces A Physicochem Eng Asp 2012; 413: 273-279, doi: 10.1016/j.colsurfa.2011.11.033.

62. Florea DA, Albuleţ D, Grumezescu AM, Andronescu E. Surface modification - a step forward to overcome the current challenges in orthopedic industry and to obtain an improved osseointegration and antimicrobial properties. Mater Chem Phys 2020; 243: 122579, doi: 10.1016/ j.matchemphys.2019.122579. 
63. Manam NS, Harun WSW, Shri DNA, Ghani SAC, Kurniawan $\mathrm{T}$, Ismail $\mathrm{MH}$, et al. Study of corrosion in biocompatible metals for implants: a review. J Alloys Compounds 2017; 698-715, doi: 10.1016/j.jallcom.2017.01.196.

64. Kaur M, Singh K. Review on titanium and titanium based alloys as biomaterials for orthopaedic applications. Mater Sci Eng C Mater Biol Appl 2019; 102: 844-862, doi: 10.1016/j.msec.2019.04.064.

65. Jesuíno GA, Ribeiro LMF, Nakazato RZ, Codaro EN, Hein $\mathrm{LR}$ de $\mathrm{O}$. Propriedades mecânicas e resistência à corrosão da liga Ti-4Al-4V obtida da reciclagem da liga Ti-6Al-4V. Mater Res 2001; 4: 63-69, doi: 10.1590/S1516-1439200 1000200004

66. Toker SM, Canadinc D, Maier HJ, Birer O. Evaluation of passive oxide layer formation-biocompatibility relationship in $\mathrm{NiTi}$ shape memory alloys: geometry and body location dependency. Mater Sci Eng C Mater Biol Appl 2014; 36: 118-129, doi: 10.1016/j.msec.2013.11.040.

67. Vojtěch $D$, Voděrová $M$, Fojt J, Novák $P$, Kubásek T. Surface structure and corrosion resistance of short-time heattreated NiTi shape memory alloy. Appl Surf Sci 2010; 257: 1573-1582, doi: 10.1016/j.apsusc.2010.08.097.

68. Sajnóg A, Hanć A, Koczorowski R, Makuch K, Barałkiewicz D. Usefulness of laser ablation ICP-MS for analysis of metallic particles released to oral mucosa after insertion of dental implants. J Trace Elem Med Biol 2018; 46: 46-54, doi: 10.10 16/j.jtemb.2017.11.007.

69. Gomes CC, Moreira LM, Santos VJSV, Ramos AS, Lyon JP, Soares CP, et al. Assessment of the genetic risks of a metallic alloy used in medical implants. Genet Mol Biol 2011; 34: 116-121, doi: 10.1590/S1415-475720100050 00118.

70. Rodríguez-Cano A, Cintas $P$, Fernández-Calderón $M C$, Pacha-Olivenza $M$ ángel, Crespo $L$, Saldaña $L$, et al. Controlled silanization-amination reactions on the Ti6Al4V surface for biomedical applications. Colloids Surfaces B Biointerfaces 2013; 106: 248-257, doi: 10.1016/j.colsurfb. 2013.01.034.

71. Dinca VC, Soare S, Barbalat A, Dinu CZ, Moldovan A, Stoica I, et al. Nickel-titanium alloy: cytotoxicity evaluation on microorganism culture. Appl Surf Sci 2006; 252: 46194624, doi: 10.1016/j.apsusc.2005.07.093.

72. Qiao S, Wu D, Li Z, Zhu Y, Zhan F, Lai H, et al. The combination of multi-functional ingredients-loaded hydrogels and three-dimensional printed porous titanium alloys for infective bone defect treatment. J Tissue Eng 2020; 11: 2041731420965797, doi: 10.1177/2041731420965797.

73. Bayat N, Sanjabi S, Barber ZH. Improvement of corrosion resistance of NiTi sputtered thin films by anodization. Appl Surf Sci 2011; 257: 8493-8499, doi: 10.1016/j.apsusc.2011. 05.001.

74. de Oliveira PGFP, Soares MSM, Silveira e Souza AMM, Taba Jr M, Palioto DB, Messora MR, et al. Influence of nano-hydroxyapatite coating implants on gene expression of osteogenic markers and micro-CT parameters. An in vivo study in diabetic rats. J Biomed Mater Res Part A 2021; 109 : 682-694, doi: 10.1002/jbm.a.37052.

75. Mokabber T, Cao HT, Norouzi N, Van Rijn P, Pei YT. Antimicrobial electrodeposited silver-containing calcium phosphate coatings. ACS Appl Mater Interfaces 2020; 12: 5531-5541, doi: 10.1021/acsami.9b20158.
76. Yu L, Santisteban TMS, Liu Q, Hu C, Bi J, Wei M. Effect of three-dimensional porosity gradients of biomimetic coatings on their bonding strength and cell behavior. J Biomed Mater Res A 2020; 109: 615-626, doi: 10.1002/jbm.a.37046.

77. Wei Y, Liu Z, Zhu X, Jiang L, Shi W, Wang Y, et al. Dual directions to address the problem of aseptic loosening via electrospun PLGA @ aspirin nanofiber coatings on titanium. Biomaterials 2020; 257: 120237, doi: 10.1016/j.biomaterials. 2020.120237.

78. Albano CS, Gomes AM, Feltran GS, Fernandes CJC, Trino LD, Zambuzzi WF, et al. Biofunctionalization of titanium surfaces with alendronate and albumin modulates osteoblast performance. Heliyon 2020; 6: e04455, doi: 10.1016/ j.heliyon.2020.e04455.

79. Yang G, Wang B, Tawfiq K, Wei H, Zhou S, Chen G. Electropolishing of surfaces: theory and applications. Surf Eng 2017; 33: 149-166, doi: 10.1080/02670844.2016. 1198452.

80. Datta M, Landolt D. Fundamental aspects and applications of electrochemical microfabrication. Electrochim Acta 2000; 45: 2535-2558, doi: 10.1016/S0013-4686(00)00 350-9.

81. Larsson C, Thomsen P, Aronsson BO, Rodahl M, Lausmaa $\mathrm{J}$, Kasemo $\mathrm{B}$, et al. Bone response to surface-modified titanium implants: Studies on the early tissue response to machined and electropolished implants with different oxide thicknesses. Biomaterials 1996; 17: 605-616, doi: 10.1016/ 0142-9612(96)88711-4.

82. Mokhtari H, Ghasemi Z, Kharaziha M, Karimzadeh F, Alihosseini $F$. Chitosan-58S bioactive glass nanocomposite coatings on TiO 2 nanotube: structural and biological properties. Appl Surf Sci 2018; 441: 138-149, doi: 10.1016/ j.apsusc.2018.01.314.

83. Albu SP, Ghicov A, Aldabergenova S, Drechsel P, LeClere $\mathrm{D}$, Thompson GE, et al. Formation of double-walled $\mathrm{TiO}_{2}$ nanotubes and robust anatase membranes. Adv Mater 2008; 20: 4135-4139, doi: 10.1002/adma.200801189.

84. Park MG, Choe HC. Corrosion behaviors of bioactive element coatings on PEO-treated Ti-6Al-4V alloys. Surf Coatings Technol 2019; 376: 44-51, doi: 10.1016/j.surfcoat. 2018.07.093

85. Santos-Coquillat $A$, Martínez-Campos E, Mohedano M, Martínez-Corriá R, Ramos V, Arrabal $\mathrm{R}$, et al. In vitro and in vivo evaluation of PEO-modified titanium for bone implant applications. Surf Coatings Technol 2018; 347: 358-368, doi: 10.1016/j.surfcoat.2018.04.051.

86. Zomorodian A, Brusciotti F, Fernandes A, Carmezim MJ, Moura e Silva T, Fernandes JCS, et al. Anti-corrosion performance of a new silane coating for corrosion protection of AZ31 magnesium alloy in Hank's solution. Surf Coatings Technol 2012; 206: 4368-4375, doi: 10.1016/j.surfcoat. 2012.04.061.

87. Dubruel P, Vanderleyden E, Bergadà M, De Paepe I, Chen $H$, Kuypers $S$, et al. Comparative study of silanisation reactions for the biofunctionalisation of Ti-surfaces. Surf Sci 2006; 600: 2562-2571, doi: 10.1016/j.susc.2006.04.021.

88. Juan-Díaz MJ, Martínez-Ibáñez M, Lara-Sáez I, da Silva S, Izquierdo R, Gurruchaga M, et al. Development of hybrid sol-gel coatings for the improvement of metallic biomaterials performance. Prog Org Coatings 2016; 96: 42-51, doi: 10.1016/j.porgcoat.2016.01.019. 
89. Batan A, Brusciotti F, De Graeve I, Vereecken J, Wenkin M, Piens $\mathrm{M}$, et al. Comparison between wet deposition and plasma deposition of silane coatings on aluminium. Prog Org Coatings 2010; 69: 126-132, doi: 10.1016/j.porgcoat. 2010.04.009.
90. Nisol B, Oldenhove G, Preyat N, Monteyne D, Moser M, Perez-Morga D, et al. Atmospheric plasma synthesized PEG coatings: non-fouling biomaterials showing protein and cell repulsion. Surf Coatings Technol 2014; 252: 126-133, doi: 10.1016/j.surfcoat.2014.04.056. 